\title{
SIVADó MÁTÉ
}

\section{A romák elleni sorozatgyilkosság néhány aspektusának kriminológiai elemzése}

\section{Criminological Analysis of Some Aspects of the Series of Murders Committed against Roma People}

Abstract: The case known in the public discourse as the Roma murders was a series of attacks on Roma committed with a distinctly anti-Gypsy, racist motive by Árpád Kiss, István Kiss, Zsolt Pető, and István Csontos - the latter having joined them later - between July 2008 and August 2009.

The perpetrators had previously committed a gun robbery in Besenyszög and then carried out firearm and Molotov cocktail attacks on Gypsies in a total of nine settlements across five counties, killing a total of six people. The investigation revealed that several of the offenders were related to the skinhead community in Debrecen, and their motive was retaliation for crimes related to gypsies and incitement of anti-Gypsy sentiments among the population.

They were arrested on 21 August 2009, in a nightclub in Debrecen, where two of the perpetrators worked as bouncers. Their criminal proceedings began on 25 March 2011, and the verdict was pronounced on 6 August 2013. The first-, second-, and third-degree defendants were sentenced to actual life imprisonment, while the fourth-order defendant was sentenced to 13 years in prison, of which he could not be released on parole, so he is expected to be released at the end of August 2022.

The publication presents the events, the process of the investigation, the arrest, and the perpetrators. The author seeks to find motivation for the events and broader social aspects.

Keywords: serial murder against gypsies in Hungary, racism, criminal investigation, criminology

Összefoglaló: A közbeszédben romagyilkosságként elhíresült ügy egy olyan támadássorozat, amelyet Kiss Árpád, Kiss István és Pető Zsolt, valamint a később csatlakozó Csontos István követtek el kifejezetten cigányellenes, rasszista indíttatásból 2008 júliusa és 2009 augusztusa között.

Az elkövetők korábban Besenyszögön fegyverrablást követtek el, majd öt megye összesen kilenc településén lőfegyverrel és Molotov-koktéllal támadást hajtottak végre cigányok ellen, amiben összesen hatan haltak meg. A nyomozás során kiderült, hogy az elkövetők közül többen a debreceni skinhead közösséggel álltak kapcsolatban, indítékuk a cigányok által elkövetett büncselekmények megtorlása és a lakosság cigányellenes indulatainak felszítása volt.

2009. augusztus 21-én fogták el őket egy debreceni szórakozóhelyen, ahol két elkövető kidobóként dolgozott. Büntetőeljárásuk 2011. március 25-én kezdődött, az ítéletet 2013. augusztus 6-án hirdették ki. Az első-, a másod- és a harmadrendű vádlottat tényleges életfogytiglani börtönbüntetésre, míg a negyedrendű vádlottat 13 év börtönbüntetésre ítélték, amelyből várhatóan 2022. augusztus végén szabadul.

A publikáció bemutatja az eseményeket, a nyomozás menetét, az elfogást és az elkövetőket. A szerző motivációt keres az eseményekhez és a tágabb társadalmi vonatkozásokhoz.

Kulcsszavak: cigányok elleni sorozatgyilkosság Magyarországon, rasszizmus, bünügyi nyomozás, kriminológia 
"- Négyéves gyereket kinyírni! Volt már itt minden tetüség, de ilyet! Ezeknek olyan keményszivü embereknek kellett lenni, hogy a föld alól kellett elöjönni! Négyéves gyereket kinyírni, aki az életet nem ismerte, csak az anyja csecsét... Egy olyan családról van szó, aki a légynek sem ártott! Az apja dolgos ember volt, rettentöen értett a dolgokhoz. Nem értem, miért történt, nem álltak senki útjába. Ennek összefüggése az én véleményem szerint semmi nincs. Itt csak találgatás van. A bünök az volt, hogy az utolsó házban éltek."

\section{Bevezetés}

Magyarországon a rendszerváltást követően feltörtek a mélyből a roma és nem roma lakosság közötti ellentétek. Erről negyven évig legfeljebb tudományos publikációkban volt ildomos említést tenni. A sok elhallgatás következtében felhalmozott indulatok elemi erővel törtek elő. Az indulatok, előítéletek, lenézés sajnos kölcsönös. A romák a nem romákat egymás között „parasztok”-ként említik, sok esetben lenézik modernebb életstílusukat. A saját tradicionálisabb szokásaikat, öltözködést, férfi-női viszonyt, gyereknevelést értékesebbnek tartják. A többség sok társadalmi problémáért: a vagyon elleni bűncselekményekért, a rossz közbiztonságért, a nyomorból való kitörésre való képtelenségért a roma lakosságot teszi felelőssé.

\section{Az elözmények}

Szögi Lajos tiszavasvári tanár két leánygyermekével 2006. október 15-én hajtott át a Borsod-Abaúj-Zemplén megyei Olaszliszkán, amikor autójának szaladt egy kislány, aki az árokba esett, de nem sérült meg. Szögi a helyszínen megállt, de addigra a kislány már elsétált. Az utcára tóduló családtagok lincseléses módon agyonverték a pedagógust, aki a helyszínen életét veszítette. Két lánya az esetet végignézte. Az elkövetők megöléssel és megerőszakolással fenyegették meg őket. Az eset országos közfelháborodást váltott ki a többség részéről a roma kisebbség irányába. A Hír Tv hosszú ideig naponta beszámolt az esetről, gyakorlatilag félóránként. A nyomozás során feltárt információk szerint a későbbi elkövetők ekkor döntötték el: polgárháborút kell kirobbantani Magyarországon romák és nem romák között.

\section{A fegyverek megszerzése}

2008. március 7-ére virradó éjszaka ismeretlen tettesek (K. Árpád, K. István és P. Zsolt, valamint egy máig ismeretlen társuk) álarcban, kesztyűben, a bejárati ajtó

${ }^{1}$ TÁBoRI Zoltán: Cigány rulett, Európa Könyvkiadó, Budapest, 2014, 234. 
befeszítésével hatoltak be G. Csaba besenyszögi házába, ahol az álmukból felébredő négyfős család tagjait megkötözték, pisztollyal kényszerítették, és a vadász foglalkozású családfő hétsörétes, illetve golyós vadászfegyverével, valamint az azokhoz tartozó lőszerekkel a helyszínről elmenekültek.

\section{Lövés a debreceni menekülttáborra}

2008. június 2-án, 0:10 óra körül, ismeretlen tettes (K. Árpád) egy Mauser típusú távcsöves puskával, 260 méter távolságból két célzott lövést adott le a Debrecen, Sámsoni út 149. szám alatti menekülttábor kivilágított, második emeleti ablakára. A lövés következtében A. Hasani szerb menekült nyolc napon belül gyógyuló, könnyű sérülést szenvedett. A rendőrség által lefolytatott helyszíni szemle során sikerült megtalálni a lövedék köpenyének egy darabkáját. Az ezen lévő huzagolási nyom később a használt fegyver egyedi azonosítását is lehetővé tette.

\section{$\overline{\text { 5. Galgagyörk }}$}

A fegyverek először itt sültek el. A merénylők azért szemelték ki, mert itt egy szövevényes szomszédviszály odáig fajult, hogy két nem cigány családot a Magyar Gárda költöztetett ki a cigánysorról, nagy sajtónyilvánossággal kísérve. A hír Debrecenbe is eljutott, ahol néhány férfi elhatározta, hogy a cigányság számlájára írt konfliktust megtorolja - a golyónyomok talán a mai napig megtalálhatók a házak falain.

2008. július 21-re virradó éjszaka ismeretlen tettesek (K. István és P. Zsolt) Galgagyörkön, a Rákóczi utcában, romák által lakott házak között gyalogosan haladva, az épületekre közvetlen közelről sörétes puskával több lövést adtak le, míg társuk (K. Árpád) a „visszavonulásukat” több száz méterről a távcsöves puskából leadott lövésekkel fedezte. A szerencsének tulajdonítható módon személyi sérülés nem történt.

A hatóság kezére kerülő tárgyi bizonyítási eszközöket [főként gyújtópalack- és lőszermaradványokat (lövedékek, töltényhüvelyek, sörétkosarak)] lefoglalták ugyan, de - nyilvánvalóan jórészt a kedvezőtlen külső körülményeknek is tulajdoníthatóan - egy részüket nem is a helyszíni szemlét végző hivatalos személyek szedték össze, hanem a szemle befejezése után tanúk találták meg és szolgáltatták be.

\section{Piricse}

2008. augusztus 8-án, 01:00 óra körül, ismeretlen tettesek (K. Árpád, K. István, P. Zsolt) Piricsén Molotov-koktélokat dobtak az Ady Endre utcai, romák által lakott épületre, és a tủz elől a házból kimenekülő Gy. Magdolnára K. István kb. nyolc méterről, 


\section{ERDÉLYI JOGÉLET}

sörétes fegyverből tüzet nyitott, ennek következtében az asszony súlyos sérülést szenvedett. A Szabolcs-Szatmár-Bereg Megyei Rendőr-főkapitányság tartott helyszíni szemlét, amelynek során lábbeli-, gépkocsikerék-futófelület-, továbbá lövedékbecsapódási nyomokat rögzítettek, valamint tárgyi bizonyító eszközöket (gyújtópalack- és lőszermaradványokat) foglaltak le. ${ }^{2}$

\section{Nyíradony}

2008. szeptember 5-én, 2:00 óra körül, a Nyíradony Tamásipuszta 2. szám alatti hatfős roma család által lakott épületre ismeretlen tettes (K. Árpád) 60-65 méterről, távcsöves puskájából két lövést adott le, amely személyi sérülést nem okozott. A helyszíni szemle során a hatóság tagjai ráleltek több lövedékmaradványra, összesen öt darab „lövedékköpenyt” foglaltak le.

\section{Tarnabod}

2008. szeptember 29-én, 1:00 óra körül, Tarnabodon, a Tarna utcában lévő (céltévesztés révén), nem romák által lakott, de elhanyagolt, szegényes épületekben élő személyek családi házaira, válogatás nélkül öt Molotov-koktélt dobtak és 28 lövést adtak le ismeretlen tettesek (K. Árpád, K. István, P. Zsolt). A támadás során személyi sérülés nem történt. A Tarnabodon megtámadott házak egyikében sem laktak romák.

A Heves Megyei Rendőr-főkapitányság bűnügyi osztálya végzett helyszíni szemlét, ennek során a megtámadott épületeken és belső tereikben lövedékbecsapódási nyomokat rögzítettek, továbbá bennük, a hozzájuk tartozó magánterületeken és mintegy kétszáz méter hosszan a Tarna utcán tárgyi bizonyítási eszközöket - gyújtópalackokat, ezek maradványait, valamint lőszermaradványokat (töltényhüvelyeket, sörétkosarakat és lövedékmaradványokat) foglaltak le.

\section{Nagycsécs}

2008. november 3-án, 1:00 óra körül ismeretlen elkövetők (K. István és P. Zsolt) Nagycsécsen, a Dózsa György út egyik családi házára Molotov-koktélokat dobtak, illetve vadászfegyverekből az épületekre lőttek, míg társuk (K. Árpád) távcsöves fegyveréből tüzelve „támogatta” társait. A Dózsa György út 8. számú ház redőnyein és ablakain áthatoló lövedékek N. Tiborné és N. József halálát okozták. A két ember halálával járó eset

${ }^{2}$ Bócz Endre: Az úgynevezett „romagyilkosságok” ügyének néhány tanulsága, Belügyi Szemle, 2017/7$8,25$. 
után nyilvánvalóvá vált, hogy az ügy eredményes nyomozása meghaladja egy megyei főkapitányság lehetőségeit, így a feladatot átvette a Nemzeti Nyomozó Iroda.

A helyszíni szemle során lövedékbecsapódási nyomokat, gyújtópalackot és gyújtópalack-maradványokat, lövedékeket és lövedékmaradványokat, töltényeket leltek, sőt egy azonosításra alkalmas lábbelitalpnyomokból álló lábnyomcsapást is rögzítettek, amit azután a bíróság részletesen fel is használt. ${ }^{3}$

\section{Alsózsolca}

2008. december 15-én, 17:00 óra körül ismeretlen tettes (K. Árpád) az Alsózsolca, Dankó Pista utca egyik épülete előtt az esti szürkületben fát aprító két személyre Mauser típusú golyós fegyverből, kb. 135 méter távolságból leadott lövéssel életveszélyesen megsebesítette R. Krisztiánt.

\section{$\overline{\text { 11. Tatárszentgyörgy }}$}

2009. február 23-án, 0:30 óra körül ismeretlen tettesek (K. Árpád, K. István és P. Zsolt) Molotov-koktéllal felgyújtották a Tatárszentgyörgy, Fenyves sor 3. szám alatti, Cs. Róbert és ötfős családja által lakott épületet, majd a tűz elől a szabadba menekülő férfit, karján a négyéves gyermekével együtt, közvetlen közelről, sörétes fegyverből leadott lövésekkel megölték.

A sértetteket kevéssel éjfél után szokatlan zaj riasztotta fel álmukból, s azt látták, hogy a lakás előterében - ahol a kisgyermekeik aludtak - ég a függöny és tüzet fogott a berendezés. Ez érthető riadalmat váltott ki. A gyermekeket a házból kimentő férjet és a kisfiút a lesben álló K. I. két lövéssel megölte. A tűz miatt a rémülettől szinte megbénult asszony - aki a harmadik gyermek kimentésére koncentrált - még az égő házban hallotta ugyan, de nem ismerte fel a lövések zaját. Bár a holttesteket megtalálták, a halál okáról még a tủz oltása idején sem volt senkinek tudomása, az özvegy közelebbről meg nem határozott robbanásról beszélt, és senki nem gyanakodott idegenkezűségre. Arra gyanakodtak, hogy a tủz a szemmel látható szabálytalan elektromos vezetéknek tulajdonítható, a sérüléseket pedig a szóbeszéd tárgyát képező, közelebbről nem tisztázott eredetủ robbanás szilánkjai okozták. A rendkívüli halál okán a Dabasi Rendőrkapitányság beosztottai közigazgatási eljárás keretében helyszíni szemlét tartottak, az orvos pedig hatósági boncolást rendelt el. Az áldozatok rokonai viszont reggel, a nappali világosságnál rábukkantak két sörétes töltényhüvelyre és egyéb lőszermaradványokra, illetve két lábnyomcsapásra, amely a leégett házat kötötte össze egy olyan erdő széli ponttal, amely gépkocsi-várakozásra tűnt alkalmasnak. Ezt bejelentették, s ezek hírére a Pest Megyei Rendőr-főkapitányság - most már büntetőeljárás keretében - helyszíni szemlét

${ }^{3}$ Bócz Endre: Az úgynevezett „romagyilkosságok” ügyéről, Belügyi Szemle, 2015/11, 156. 
tartott. A szemle során rögzítették egy várakozó gépkocsi egyedi azonosításra alkalmatlan nyomait, illetve több személy innen a leégett házhoz (és vissza) vezető, szintén azonosításra alkalmatlan lábnyomcsapását, és lefoglalták az áldozatok rokonsága által felfedezett, valamint a szemle során talált lőszermaradványokat és egy sörösüveg hat centiméteres szilánkját, amely gyújtópalack-maradványnak tủnt.

\section{Tiszalök}

2009. április 22-én, 22:00 órakor, Tiszalökön ismeretlen tettes (K. Árpád), társai támogatásával (K. István, P. Zsolt, Cs. István) golyós vadászfegyverből leadott egyetlen lövéssel megölte a Nefelejcs utcai, kivilágított családi házból kilépő és éppen munkába induló K. Jenőt. A helyszíni szemlén tárgyi bizonyítás eszközöket nem foglaltak le.

\section{Kisléta}

2009. augusztus 3-án, 2:00 óra körül ismeretlen tettesek (K. Árpád, K. István. P. Zsolt és Cs. István) behatoltak a Kisléta, Bocskai utca 7. szám alatti házba, ahol közvetlen közelről leadott lövésekkel megölték az ágyban fekvő B. Máriát, míg leányát, P. Tímeát életveszélyesen megsebesítették. ${ }^{4}$

\section{Az emberölés-sorozat felderitésének föbb irányai}

14.1. A helyszíni vonalon adatgyủjtést folytattak a bủncselekmények közvetlen és tágabb környezetében. Elszámoltatták az állandó lakosokat, és ellenőrizték a községek átmenő forgalmát. A büncselekmény elkövetése után azonos napokon és napszakokban is visszatérő módon folytatták az adatgyüjtést. Beszerezték és elemezték az érintett településeken, illetve a településekhez vezető útvonalakon működő biztonsági kamerák és térfigyelő rendszerek felvételeit.

14.2. A szakértői vonalon, az igazságügyi orvos szakértőkön kívül kiemelést érdemel a Bünügyi Szakértői és Kutatóintézet (akkoriban: BSZKI, ma Nemzeti Szakértői és Kutató Intézet, NSZKK) valamennyi szakértőosztálya közül is a nyom-, illetve a fegyverszakértői terület, de mindenekelőtt a genetikai szakértői osztály tevékenysége. E szakértői ágak képviselői már a felderítés szakaszában egzakt, egyúttal orientáló véleményeikkel voltak a hatóságok segítségére. A fegyverek és lőszerek azonosításán túl a fel nem robbant Molotov-koktélokról készítettek a későbbi azonosításhoz elengedhetetlen genetikai profilokat, illetve megállapították két ismeretlen elkövető rokonsági, testvéri kapcsolatát is.

${ }^{4}$ PetőFi Attila: A 2008-2009-es romagyilkosság-sorozat nyomozása, Belügyi Szemle, 2017/7-8, 40. 
13.3. A sértetti vonalon az egyes sértettek életvitelét, előéletét és kapcsolatrendszerét próbálták tisztázni, valamint a sértettek közötti direkt és indirekt kapcsolat lehetőségét.

13.4. A fegyver-lőszer vonalon valamennyi kereskedelemmel foglalkozó cégét megvizsgáltak.

14.5. Hívásforgalmi adatok nyomán az egyes bủncselekmények helyszínein, illetve a megközelítési és távozási útvonalain telepített mobil-átjátszóállomások forgalmát értékelték és elemezték, valamint az egyes toronyforgalmi adatokat a közös telefonszámok kiszűrése érdekében összehasonlították. Megközelítőleg ötmillió hívásadatot tartalmazó elemzőmunka mellett a nyomozás során felvetődő célszemélyek kizárását is részben így végezték el.

14.6. A közútforgalmi adatok vonalán, az autópályákon vásárolt matricák révén folytattak adatgyủjtést, valamint a forgalmat ellenőrző kamerák nyolcszáz órányi felvételeit elemezték, és több mint 1,8 millió gépkocsival kapcsolatos adatot értékeltek.

14.7. A bejelentési vonalon a sajtótevékenységnek és a százmillió forintra emelt nyomravezetői díjnak tulajdonítható módon, 460 személyre szóló bejelentés érkezett. Egyébiránt a nyomozás teljes folyamatát rendkívül nagy érdeklődés kísérte a médiumok és a közvélemény részéről. „A nyomozati szakasz, különösen a rendőrség tevékenysége, felülreprezentált a híradásokban, amint az ügyek távolabb haladnak, egyre inkább csökken a híradások száma és az érdeklödés."5

14.8. A „bosszúvonal”: A bủncselekmény-sorozat hátterében állhat-e az, hogy az ismeretlen tettesek vagy hozzátartozóik sérelmére, esetleg romák követhettek el bủncselekményt? Több mint 1300 személy elleni erőszakos bủncselekmény nyomozati iratait értékelték.

14.9. A szélsőséges csoportok vonalán a társszervekkel együtt ellenőrizték az e csoportokat alkotó személyeket. ${ }^{6}$

\section{A lebukás}

A híváslisták kiértékeléséből kiderült, hogy a később elkövetőként azonosított személyek a galgagyörki és a tiszalöki helyszínen ugyanazokat a munkatelefonokat használták, de az eddigi forgalmazási fegyelmet az utóbbi helyszínen megszegve, nemcsak egymással, hanem egy „civil” számmal is kommunikáltak. Később, a gyanúsítottak elfogása után derült ki a banánhéjnak tekinthető telefonhívások háttere.

Helyszínfelmérés közben Balmazújváros térségében az elkövetők járműve elakadt a felázott földúton. Ekkor K. Árpád kénytelen volt az eddig csak egymás közötti kommunikációra használt telefonjával 3:46-kor felhívni barátnőjét, F.-né Ny. Évát. A nő a helyszínre autózott, az Opelt traktorral kivontatták a sárból.

${ }^{5}$ VÁRI Vince: A média és a rendôrség iránti bizalom, Magyar Rendészet, 2016/4, 79.

${ }^{6}$ Petőfi: i. m., 56. 


\section{Az elfogás}

Az F.-né kezében lévő készülék hívószáma nyomán jutottak el a használó személyhez, majd a debreceni Perényi 1 elnevezésủ szórakozóhelyhez, valamint a klub alkalmazásában álló, szélsőséges ideológiát valló alkalmazottakhoz, a tényleges elkövetőkhöz.

A telefonos információ felvetődése után tíz nappal, 2009. augusztus 21-én, a hajnali órákban, előre meghatározott terv szerint több mint háromszáz (NNI-s, illetve más társszerveknél dolgozó) kolléga összehangolt művelete nyomán, az említett szórakozóhelyen történt meg K. Árpád, K. István és P. Zsolt egyidejű elfogása. Az elszámoltatások és az adatgyüjtések során terhelő adatok merültek fel Cs. Istvánra is, akinek elfogására néhány órával később került sor.

\section{Az elkövetök}

- Kiss Árpád (42) az értelmi szerző, zenekari dobos, radikális szélsőjobboldali.

- Kiss István (33) szakács, skinhead, a debreceni focicsapat szurkolói kemény magjának tagja.

- Pető Zsolt (34) cukrász, kutyatenyésztő szimpatizált az idegengyủlölő, kirekesztő eszmékkel. A szélsőséges közösséghez tartozását ruházatával és tetoválásaival is jelezte, tóraégetéssel vádolták.

- Csontos István (27) hidegburkoló, korábban a KFOR misszió keretében katonaként szolgált Koszovóban. Katonai pályafutása idején megszakította a kapcsolatait neonáci szemléletü társaságával. 2022. augusztus 21-én szabadul a rá kiszabott 13 év fegyházbüntetés teljes letöltése után.

\section{Az ítélet}

Kiss Árpádot, Kiss Istvánt és Pető Zsoltot tényleges életfogytig tartó szabadságvesztésre ítélték, és tíz évre eltiltották a közügyektől. Csontos István 13 év fegyházat kapott. A négy elítéltnek meg kell fizetnie 107 millió forint perköltséget is.

A tanácsvezető bíró szóbeli indokolásában kimondta a rasszista indítékot. Hangsúlyozta, erkölcsileg elvetendő, egyetlen országban sem megengedhető, hogy valakik egy etnikum megrendszabályozása, megzabolázása, megfélemlítése céljából szövetkezzenek bủncselekmények elkövetésére.A rasszista indíték nem csak a tanúk vallomásaiból nyilvánvaló, de még maguk a vádlottak sem tagadták - tette hozzá. ${ }^{7}$

${ }^{7}$ A Budapest Környéki Törvényszék 8 B. 101/2010/1010. számú ítélete. 


\section{A büncselekmény-sorozat utóélete, felmerülö kérdések}

- Nyilvánvalóan nem került minden elkövető a gyanúsítotti körbe, a szervezők, tippadók teljességgel ismeretlenek maradtak. Az eljárás alá vont elkövetőknek szervezői készsége, illetve anyagi eszköze nyilvánvalóan nem volt elegendő a bűncselekmények megszervezéséhez, elkövetéséhez.

- Felmerült szélsőséges politikai szervezetek támogatása, szervezőmunkája, de ez a szál felderítetlenül maradt.

- A fegyverrablás módját apró részletekig sikerült tisztázni, nem derült fény az öszszes lőszer eredetére, illetve az egyik elkövető kilétére. A vádirat szerint ugyanis a rablásban egy máig ismeretlen tettestársuk is részt vett, akár közvetlenül vagy közvetve a támadások ideje alatt, az ő kilétüket sem sikerült a mai napig megállapítani.

- Az elfogás során két másik személyt is előállított a rendőrség, akiknek a neve már az elfogás előtt is képbe került. R. Antal és E. László a rendőrségi jelentés szerint „a büncselekmény elkövetésével gyanúsitható, köze van az elkövetéséhez, tudomással bír a végrehajtásban és szervezésében részt vevő személyekről, a cselekmények elözményeiről, az elkövetés eszközeinek hollétéről”. A két személyt, miután a többiekkel együtt elfogták, házkutatást tartottak náluk, ám végül mégsem gyanúsították meg őket a bủncselekményekkel.

- Felmerült külföldi titkosszolgálatok szervezőmunkája, de konkrét bizonyítékot nem találtak erre a hatóságok.

- Hazai titkosszolgálatok közreműködése:

1. Kiss Istvánt a Nemzetbiztonsági Hivatal (NBH) 2008 májusáig megfigyelte.

2. Csontos István negyedrendủ vádlottról kiderült, hogy a Katonai Biztonsági Hivatal titkos kapcsolata volt, egykori tartótisztje azonban felsőbb utasításra letagadta a kapcsolatukat, hamis tanúzás miatt a bíróság is feljelentette.

\section{A honvédelmi minisztérium belsö vizsgálata}

A honvédelmi vezetés 2010-ben belső vizsgálatot folytatott le az ügyben. Csontos tartótisztje, H. Ernő fegyelmit kapott, a vizsgálat szerint több hibát is ejtett, amikor kapcsolatot tartott az egykori katonával. Megsértette például a szolgálati szabályzatot, azzal, hogy Csontos István ismerte H. Ernő privát telefonszámát, és járt H. Ernő lakásán, vagyis tisztában volt azzal, hogy a tiszt hol lakik. H. Ernő a szaktárca által elrendelt belső vizsgálat szerint számos információt nem dokumentált, a találkozókról szóló írásos jelentése sem teljes.

A Magyar Nemzet úgy tudja, több olyan bűncselekményre, illetve szolgálati szabálysértésre utaló adat is felmerült, amelyek alapján évekkel ezelőtt büntetőeljárást lehetett volna indítani, ám az eltelt idő alatt ezek az ügyek elévültek. Így az utólagos nyomozás zsákutcába futott. Az ügyet azonban korántsem lehet lezárni. Szakmai, elsősorban titkosszolgálati körökben makacsul tartja magát, hogy a felbujtó, felbujtók 
személye előbb-utóbb ismertté válik, akár úgy is, hogy büntetőjogilag el tudják majd számoltatni őket. ${ }^{8}$

\section{Kiss Árpád levele 2020-ban}

Kiss Árpád elítélt ügyvédje, Józsa Edina útján levelet küldött a Pesti Srácok portálnak 2020-ban: „A 2008. évi galgagyörki pogromot mindenki büntetlenül úszta meg. Pedig ez a kézivezérelt esemény inditotta el a hat áldozat halálával végződött, szegregátumok elleni támadássorozatot. Itt nem valamiféle absztrakt összefüggésröl van szó. Nem véletlen, hogy a gyilkosságokhoz vezetö első támadás szintén Galgagyörkön történt, a tipp és az anyagi eszközök a Jobbikkal kapcsolatban álló, ultraradikális körtől származtak. Ez a szponzoráció akkor sem hátrált meg, amikor 2008. november 2-án éjjel Nagycsécs település határában, Pető Zsolt elitéltnél elszakadt a cérna, és kivégzett egy családot. Legkésőbb ekkor az elfogáshoz szükséges összes információ már rendelkezésre állt, a szokásos kriminalisztikai adatokat a rendörség összegyuujtötte, de az ismert, eröszakra hajlamos neonácik aktáit a Laborc Sándor, később Ficsor Ádám irányitása alá rendelt Nemzetbiztonsági Hivatal (NBH) visszatartotta" - írta levelében Kiss Árpád. ${ }^{9}$

\section{$\overline{\text { 21. Új nyomozások }}$}

Az ügyben a Készenléti Rendőrség Nemzeti Nyomozóiroda és a Terrorelhárítási Központ indított titkos nyomozást a fegyverrablásoknál részt vevő fel nem derített elkövető kilétének megállapítására, illetve előbbi szerv a felbujtók kilétének megállapítására indított nyílt nyomozást. Ezen eljárások eredményre eleddig nem vezettek.

\section{Befejezés}

A történtek kétséget kizáróan Magyarország nemzeti tragédiái közé tartoznak. Sajnos egyértelmű bizonyítékot szolgáltatnak arra, hogy a roma kisebbség problémáival el sem kezdtünk szembenézni. Gyakorlatilag két összeegyeztethetetlen álláspont néz szembe egymással. A többségi vélekedés a romákat eredendően, születésüknél fogva csökkent értékủnek, kevésbé intelligensnek, a bűnözésre inkább hajlamosnak

${ }^{8}$ Hamisan tanúzott Csontos István tartótisztje:

https://www.origo.hu/itthon/20130813-hamisantanuzott-csontos-istvan-tartotisztje.html (letöltés ideje: 2021.11 .26 .)

9 PÁmER Dávid: Újra keresi a rendôrség a romagyilkosságok felbujtóit - A halálbrigád vezetője állitja: jobbikos körök támogatták őket, Pesti Srácok internetes portál, https://pestisracok.hu/ujrakeresi-a-rendorseg-a-romagyilkossagok-felbujtoit-a-halalbrigad-vezetoje-allitja-jobbikoskorok-tamogattak-oket/ (letöltés ideje: 2021. 11.26.) 
tartja. A liberális, jogvédő álláspont ezzel szemben a többség érzéketlenségét, befogadásra való hajlandóságának a hiányát, ezáltal a romák kirekesztését okolja a kialakult helyzetért. Mint oly sokszor, a megoldás vélhetően valahol a két szélső álláspont között helyezkedik el.

A helyzet felmérését egyértelműen akadályozza, hogy a cigányság vonatkozásában nem rendelkezünk adatokkal. Mivel a kisebbséghez való tartozás szenzitív adat, annak vállalására, megvallására senki sem kényszeríthető. A rendszerváltás előtti évtizedekben a rendőrség rögzítette a bünügyi statisztikában, hogy az elkövető cigány származású. Természetesen a módszertan problémás, mert az eljáró rendőr észlelésére bízták a származás megállapítását. A romákra vonatkozó adatok hiánya azt is megakadályozza, hogy a romákra nézve kedvező, pozitív diszkriminációt alkalmazó programok indulhassanak. ${ }^{10}$

Az Amerikai Egyesült Államokban ezzel szemben a rendőri intézkedés első percétől nyilvántartják az eljárás alá vont személy vélt származását. Az adatot rögzítik a büntetőeljárásban, majd a büntetés-végrehajtása során egyaránt. Így pontosan tudhatjuk, hogy a gyanúsítottak, illetve a börtönlakosság mekkora része afroamerikai, ázsiai, latino vagy kaukázusi (fehér bőrủ európai) származású. Így van lehetőségük a helyzet felmérésére is, majd ebből kiindulva megoldási lehetőségeket kidolgozni. Nyilvánvalóvá vált, hogy az afroamerikai lakosság magas bünözési felülreprezentáltsága közvetlenül összefügg azzal, hogy a populáció jelentős része kilátástalan mélyszegénységben él. Ezen adatok alapján történnek az USA-ban az afroamerikai lakossággal kapcsolatos szociálpolitikai intézkedések, kedvezményes ösztöndíjak odaítélése, kedvezményes lakhatás, egészségügyi ellátás biztosítása. Ennek eredményeképpen az USA ma már jelentős létszámú, afroamerikai származású középosztállyal rendelkezik.

Ezekből a jelenségekből kiindulva talán felvethető, hogy a cigányság helyzetének előmozdításához legelőször az alapvető, velük kapcsolatos adatkat kellene rögzíteni.

\section{Irodalomjegyzék}

1. Bócz Endre: Az úgynevezett „romagyilkosságok” ügyének néhány tanulsága, Belügyi Szemle, 2017/7-8.

2. Bócz Endre: Az úgynevezett „romagyilkosságok” ügyéről, Belügyi Szemle, 2015/11.

3. Petőfi Attila: A 2008-2009-es romagyilkosság-sorozat nyomozása, Belügyi Szemle, 2017/7-8.

4. Pulay Gyula: Az etnikai hovatartozás számbavételi lehetőségei és szükségessége, Esély: társadalom- és szociálpolitikai folyóirat, 2009/4.

5. TÁBori Zoltán: Cigány rulett, Európa Könyvkiadó, Budapest, 2014.

6. VÁRI Vince: A média és a rendőrség iránti bizalom, Magyar Rendészet, 2016/4.

${ }^{10}$ Pulay Gyula: Az etnikai hovatartozás számbavételi lehetőségei és szükségessége, Esély: Társadalomés szociálpolitikai folyóirat, 2009/4, 35. 


\section{ERDÉLYI JOGÉLET}

\section{Források}

1. https://www.origo.hu/itthon/20130813-hamisantanuzott-csontos-istvan-tartotisztje.html (letöltés ideje: 2021. 11.26.)

2. https://pestisracok.hu/ujra-keresi-a-rendorseg-a-romagyilkossagok-felbujtoit-a-halalbrigadvezetoje-allitja-jobbikos-korok-tamogattak-oket/ (letöltés ideje: 2021.11. 26.) 